\title{
Chapter 10 \\ Identification and Acceleration of Farmer Innovativeness in Upper East Ghana
}

\author{
Tobias Wünscher and Justice A. Tambo
}

\begin{abstract}
The generation of innovations has traditionally been attributed to research organizations and the farmer's own potential for the development of innovative solutions has largely been neglected. In this chapter, we explore the innovativeness of farmers in Upper East Ghana. To this end, we employ farmer innovation contests for the identification of local innovations. Awards such as motorcycles function as an incentive for farmers to share innovations and develop new practices. The impact of Farmer Field Fora is evaluated by matching non-participants to participants using propensity scores of observable characteristics. The results indicate that farmers do actively generate and test innovative practices to address prevalent problems. Moreover, this innovative behavior can be further stimulated by Farmer Field Fora, which were tested to significantly and positively affect innovation generation.
\end{abstract}

Keywords Innovation policy • Award • Contest • Upper East Ghana • Innovation behavior

\section{Introduction}

Global change forces farmers to adapt more rapidly to changing conditions than ever before. The generation of innovations that address these global challenges can be part of the adaptation portfolio. Earlier work of ours has established a robust causal relationship between farmer innovativeness and the resilience of farmers in terms of increased household income, consumption expenditure, food security, and reduction of the length of food shortages and the severity of hunger (Tambo and Wünscher 2014). While innovations are traditionally developed by research organizations for adoption by farmers, the farmer's own potential for the generation of innovative solutions has largely been neglected. Yet, farmer innovations have the advantage of having been developed within the environment in which the farmer operates. As such, they are likely to be adapted to local constraints and can be

T. Wünscher $(\bowtie) \cdot$ J.A. Tambo

Center for Development Research (ZEF), University of Bonn, Bonn, Germany

e-mail: tobias.wuenscher@uni-bonn.de; tambojustice@yahoo.com

F.W. Gatzweiler, J. von Braun (eds.), Technological and Institutional Innovations for Marginalized Smallholders in Agricultural Development,

DOI 10.1007/978-3-319-25718-1_10 
expected to have good dissemination potential. Externally developed practices, on the other hand, i.e., those that were developed by non-farmer institutions such as universities, national and international research centers, often do not effectively address binding constraints among smallholders (Christensen and Cheryl 1994).

A local farmer innovation is defined here as a technology, practice or institution along the food chain which is different from common or traditional practice and which is developed primarily by a farmer or a group of farmers without external assistance, such as by extension agents, researchers or development workers. Likewise, a local farmer innovator is someone who has developed an innovation as defined above. In this, our definition is different from the one used by Rogers (2003) and the general adoption literature where an innovator is usually referred to as the farmer who is among the first to adopt a newly introduced technology.

Capital and formal knowledge constraints, as well as risk aversion and other factors, also set limits on what a farmer can do in terms of generating innovations. Farmer-based innovations are, therefore, to be seen as a complement and not a substitute to the traditional innovation system.

In this chapter, our objective is to assess whether farmers in one of the poorest regions of Ghana (Upper East Ghana) do, in fact, generate local innovations, and whether a newly introduced problem-solving instrument (Farmer Field Fora) can further stimulate innovative behavior, thereby increasing adaptation potentials for global change. Farmer Field Fora (FFF) are a platform for mutual learning and the development of technological and managerial solutions among agricultural stakeholders, particularly farmers, extension agents and researchers (Gbadugui and Coulibaly 2010). For the identification of local innovations, we employ a farmer innovation contest. Awards such as motorcycles function as an incentive for farmers to share innovations.

Awards are required under certain circumstances to overcome the secrecy of an innovation, or if innovations are simply not observable in the field. Reasons for secrecy include, for example, if the innovation gives the innovator a commercial advantage (Scotchmer 2004).

The paper continues with a section that outlines the implementation steps of the farmer contest and presents first results. Section "Impact Evaluation of Farmer Field Fora" presents the study details and results of the impact evaluation of Farmer Field Fora. We close in section "Conclusion".

\section{Farmer Innovation Contest}

The farmer innovation contest was implemented in Upper East Ghana. All farmers in Upper East Ghana were eligible and women were particularly encouraged to apply. Awards such as motorcycles, water pumps and roofing sheets served as incentives to share innovations with us. The contest was primarily announced through the local extension service of the Ministry of Food and Agriculture (MOFA). In workshops, extension agents were informed about the details of the 
contest. The extension agents' role was to spread the information within the study area, search for innovations, help farmers fill out the application form, and deliver the application forms to us. The extension agents were incentivized with a monetary award for each eligible application submitted. Received applications were scored by an independent selection committee. The selection committee consisted of eight members from four local stakeholder groups (farmers, MOFA, NGOs and research), each with two representatives. The selection committee members scored the applications on four criteria, namely innovativeness, economic potential, dissemination potential, and environmental and social sustainability. Scores ranged from zero to three. Zero represented no compliance (e.g., not innovative) and three represented highest compliance (e.g., highly innovative). If an application received zero for innovativeness, it was excluded from further consideration. Otherwise, the scores were added up and applications with the highest overall score were shortlisted for field visits. In the field, the selection committee members interviewed the applicant and, where appropriate, neighbors and other family members. The winners were then selected by the committee members in a final workshop. The awards were handed over in a ceremony on National Farmers' Day, which is organized by MOFA.

Between 2012 and 2013, we received 92 eligible applications (see Appendix 1). Table 10.1 shows the majority of applicants to have been male and, with a mean age of 47, mature and experienced farmers. Only three applications were received from farmer groups. We only received two applications with institutional innovations. All but two applications described innovations that were technical in nature. On average, the techniques were developed and implemented approximately a decade before the contest. This indicates that the innovations were not developed in response to the contest. The contest rather identified already existing innovations.

Most of the applications received addressed problems in animal husbandry, followed by post-harvest techniques for the storage of grain and seeds and the processing into higher level products (silage and yoghurt) (Table 10.2). Innovations in animal husbandry and crop management mostly addressed animal health and phytosanitation using local herbs. The effectiveness of these health- and phytosanitation-oriented innovations were generally difficult to assess within the context of the short field visits of the innovation contest because their functioning depended on often unknown ingredients of the herbs and their effectiveness could not intuitively be judged. All innovations required further evaluation in scientific

Table 10.1 Descriptive statistics of 92 applications (standard deviation in brackets, if applicable)

\begin{tabular}{l|l}
\hline Variable & \\
\hline Proportion of males (\%) & 79 \\
\hline Mean age of applicants (years) & $47(13)$ \\
\hline Number of group applications & 3 \\
\hline Proportion of technical innovations & $98 \%$ \\
\hline Mean year of development & $2001(14)$ \\
\hline Mean year of implementation & $2003(13)$ \\
\hline Mean number of adopters & $51(109)$ \\
\hline
\end{tabular}


Table 10.2 Type of applications received in 2012 and 2013

\begin{tabular}{|c|c|c|}
\hline Type of application & $\#$ & Comments \\
\hline \multicolumn{3}{|l|}{ Animal husbandry } \\
\hline Poultry & 27 & $\begin{array}{l}20 \text { of these to treat sicknesses, } 2 \text { for feeding, } 4 \text { for breeding, } \\
\text { poultry housing (1) }\end{array}$ \\
\hline Livestock & 12 & of these, 12 for treatment of sicknesses \\
\hline Fish & 1 & Fish feed formula \\
\hline Other & 1 & Dog treatment \\
\hline Subtotal & 41 & \\
\hline \multicolumn{3}{|l|}{ Storage } \\
\hline $\begin{array}{l}\text { Treatment of seed/ } \\
\text { grain }\end{array}$ & 14 & $\begin{array}{l}\text { Use of different plants as treatment agent: Neem (4), Barakuk } \\
\text { (1), Ash (1), Sheatree bark (1), Kwasuik plant (1), Dabokuka } \\
\text { plant (1), Salt solution (3), Bicycle tubes (1), other (1) }\end{array}$ \\
\hline Fermentation & 1 & Production of silage \\
\hline $\begin{array}{l}\text { Storage } \\
\text { management }\end{array}$ & 1 & Cooling and ventilation of sweet potatoes \\
\hline Subtotal & 16 & \\
\hline \multicolumn{3}{|l|}{ Crop management } \\
\hline Phytosanitary & 15 & $\begin{array}{l}\text { Treatment of pests, termites, nematodes and weeds using Neem, } \\
\text { Yookat, onion, tiger ants, Wacutik plant, diesel mixture, salt (9), } \\
\text { Gloriosa fruit (1), other (2), prevention of pests applying onion } \\
\text { seed inoculation (1), Neem leaves liquid spraying (1), prevention } \\
\text { of worm infestation using millet seeds (1) }\end{array}$ \\
\hline $\begin{array}{l}\text { Production of plant- } \\
\text { ing material }\end{array}$ & 1 & Multiplication of sweet potato \\
\hline $\begin{array}{l}\text { Introduction of new } \\
\text { crops }\end{array}$ & 3 & $\begin{array}{l}\text { Introduction of crops from the south of Ghana (2), mushroom } \\
\text { production (1) }\end{array}$ \\
\hline Irrigation & 1 & Growing maize in dry season \\
\hline Subtotal & 20 & \\
\hline \multicolumn{3}{|l|}{$\begin{array}{l}\text { Water/soil } \\
\text { conservation }\end{array}$} \\
\hline Water conservation & 1 & Recycling of fish pond water for irrigation and fertilization \\
\hline Soil conservation & 4 & $\begin{array}{l}\text { Use of innovative mixture of animal dung, liquid manure, zero } \\
\text { tillage }\end{array}$ \\
\hline Subtotal & 5 & \\
\hline \multicolumn{3}{|l|}{$\begin{array}{l}\text { Processing \& } \\
\text { Marketing }\end{array}$} \\
\hline Adding value & 1 & Making yoghurt from cow's milk \\
\hline Subtotal & 1 & \\
\hline Trees and Forest & 4 & $\begin{array}{l}\text { Forest management and conservation, afforestation, trees for } \\
\text { control of microclimate }\end{array}$ \\
\hline Other & 5 & $\begin{array}{l}\text { Human health, farm products against Malaria, community-based } \\
\text { extension agents, use of dogs for animal security, repellent for } \\
\text { snakes }\end{array}$ \\
\hline Total & 92 & \\
\hline
\end{tabular}


trials, but within the evaluation of the contest, scoring was based on intuition, observation, conviction and trustworthiness of the applicant. We also received a couple of innovations in soil and water conservation. For illustration, we present some of the innovations in more detail below.

\section{Case 1: Using Fish Pond Water as Liquid Manure and Insecticide}

Joseph Abarike Azumah, a fish farmer from Zuarungu, uses animal droppings such as cow, sheep and goat dung, as well as poultry manure, to supplement his locallyprepared fish feed. The fish then feed on the dung and add their own feces to the water. The water is recycled for gardening as natural manure. The innovation addresses the problem that nutrient rich water would normally be lost if it was released into the environment without further use. Its use as liquid fertilizer reduces the dependence on artificial fertilizer and also reduces the environmental impact. It is possible to combine this technique with the treatment of pests by soaking neem tree leaves in the pond in moderate quantities for it to be non-toxic to the fish. The water then acts as insecticide. The system was developed and implemented in 2008 and has been adopted by 25 farmers since.

\section{Case 2: Use of 'Barakuk' to Store Seed}

The Barakuk herb is harvested, dried and burned. The ash is then mixed with onion seed to prevent insects from attacking the seed. The process improves germination. Access to the herb was a problem during the development stage. However, the innovator, John Akugre Anyagre from Tilli, also experimented and succeeded in growing the herb on-farm, making the material readily available. One hundred and twenty farmers are known to have adopted the technique.

\section{Case 3: Controlling Striga in Millet and Sorghum Fields Using Dried Onion Leaves}

Striga is a common and severe problem in Africa. Abdul Rhaman Abieli from Missiga discovered that areas on his millet and sorghum fields where his family had dumped the leafy residues of onion production were free of striga in the following year. In order to scale up the application of onion leaves, they experimented with smaller quantities of onion and found the effect to persevere. Today, the onion leaves are pounded into powder and then mixed with the seed of millet or sorghum. Small amounts of water are sprinkled onto the powder to help it stick to the seed. One ball of dried onion leaves, the size of a fist, is enough to treat the seeds for one acre of onions. These small quantities rule out a fertilization effect. The innovation has been functional since 2001 and is known to have been adopted by approximately 50 farmers.

\section{Impact Evaluation of Farmer Field Fora}

As already indicated, this section addresses the impact of Farmer Field Fora on farmer innovativeness. 


\section{Farmer Field Fora}

Farmer Field Fora (FFF) of the Root and Tuber Improvement and Marketing Programme (RTIMP) in Ghana are based on the successful implementation of the Root and Tuber Improvement Programme (RTIP) between 1999 and 2005. The RTIMP was initiated as a follow-up project, with major funding from the International Fund for Agricultural Development (IFAD). The RTIMP supports root and tuber crop production, increased commodity chain linkages and upgrading of technologies and skills within the value chain. The aim is to enhance income and food security to improve livelihoods of the rural poor and to build a market to ensure profitability at all levels of the value chain.

The RTIMP used the FFF as a platform for mutual learning among stakeholders in the root and tuber value chain, particularly farmers, extension agents and researchers. The main aim of FFF is to "build the capacities of farmers to become experts in the development of technologies and managerial practices to solve specific problems within the agro-ecological context of farming" (Gbadugui and Coulibaly 2010). It is a variant of the well-known Farmer Field School (FFS), a participatory extension model. The FFS approach was first introduced in Indonesia in the late 1980s by the FAO to help farmers deal with the pesticide-induced pest problems in irrigated rice, but has since spread to at least 78 countries and is highly promoted by many development agencies (Braun et al. 2006). Though it was mainly introduced to promote integrated pest management (IPM) practices in rice farming, its methods have been adapted to suit different farming activities and even non-farm topics in Africa (Braun et al. 2006; Davis et al. 2012). Unlike FFS, which gives little or no attention to farmer-developed innovations (Reij and Waters-Bayer 2001), FFF provides an opportunity for farmers to experiment with their own innovations, thereby strengthening their decision-making and innovation capacities.

The RTIMP-FFF in Ghana, which started in 2006, aims at improving farmer innovation and productivity of root and tuber crops in major production districts of the country. In each participation district, the FFF was developed for the most important root or tuber crop. This study is based on the sweet potato FFF in ten communities in three northern districts of Ghana. The main actors include researchers, extension agents, business advisors, farmers and processors, and they are all placed on an equal footing. During a participatory rural appraisal, the farmers determine the theme of the FFF, thereby ensuring that their priorities are addressed. The thematic areas normally selected by the farmers include improved crop varieties, integrated pest management (IPM), improved cultivation practices and integrated soil fertility management. There are also discussion sessions on non-farm topics. Each forum consists of a group of 30-40 farmers together with other key actors who meet regularly (usually weekly) in the field during a growing season. They engage in comparative experimentation using three plots: farmers practice (FP), integrated crop management (ICM) and participatory action research (PAR), with the assistance of a facilitator who stimulates critical thinking and discussions 
and ensures active participation. The participating farmers experiment with their own innovations or test new ideas on the PAR plots. Conventional practices and improved innovations are implemented on the FP and ICM plots, respectively.

There are many studies looking at the impact of farmer field schools (FFS) on outcome variables such as empowerment, technology adoption, household income and food security, but with inconclusive findings (for a review, see Braun et al. 2006; Davis et al. 2012, Table 10.1). Within this vast literature, however, there is little, if any, on the farmer innovation effects of FFS. This chapter provides empirical evidence on the potential of FFF, a variant of FFS, in stimulating innovation-generating behavior among farm households.

\section{Empirical Method}

We are interested in estimating the effect of FFF participation on farmer innovation. The challenge is that participation in FFF is voluntary; hence, farmers self-select to participate. Thus, participating farmers may differ systematically from non-participants in observed characteristics such as education, age and wealth, and unobserved characteristics such as entrepreneurship, risk behavior or motivation which might lead to biased estimates of the effect of FFF on innovation. Due to the self-selection bias, participants and non-participants are not directly comparable. To minimize this problem, we use propensity score matching (PSM), a non-parametric technique suggested by Rosenbaum and Rubin (1983). It involves matching FFF participants with non-participants who are similar in terms of observable characteristics (Caliendo and Kopeinig 2008). Though it only accounts for observables, it is less restrictive, as it does not impose any functional form assumption, which is a challenge with other estimation techniques, such as instrumental variable regression. We also try to minimize the bias stemming from unobserved heterogeneity by controlling for household risk preferences.

In the PSM, a probit regression was estimated using several covariates to obtain a household's propensity to participate in FFF. These covariates comprise household socio-demographic and economic variables (e.g., age, gender and education of the household head; household size and dependency ratio; access to services and the wealth position of the household). It also includes households' risk preferences. ${ }^{1}$ We then use the propensity scores obtained in the first stage to match participants and non-participants in FFF. As a matching algorithm, we used kernel matching with a bandwidth of 0.3 , but, for the robustness check, radius matching with a caliper of 0.05 and nearest-neighbor matching are also employed. ${ }^{2}$ We conducted a matching quality test (Rosenbaum and Rubin 1983) to check if the balancing

\footnotetext{
${ }^{1}$ We measured households' subjective risk preferences using the Ordered Lottery Selection Design with real payoffs (Harrison and Rutström 2008).

${ }^{2}$ For a review of the different matching techniques, see Caliendo and Kopeinig (2008).
} 
property is satisfied. Based on the kernel matching, ${ }^{3}$ the test result (in Appendix 2) shows that, in contrast to the unmatched sample, there are no statistically significant differences in covariates between participants and non-participants in FFF after matching. Thus, the balancing requirement is satisfied. Using the PSM, we compute the average treatment effect on the treated (ATT):

$$
A T T^{P S M}=E[Y(1) \mid F F F=1, P(X)]-E[Y(0) \mid F F F=0, P(X)]
$$

where $Y(1)$ and $Y(0)$ are the outcome variable (farmer innovativeness) for FFF participants and non-participants, respectively; FFF is a treatment indicator which is equal to 1 if the household is FFF participant and 0 otherwise; and $\mathrm{P}(\mathrm{X})$ indicates the probability of FFF participation given characteristics $\mathrm{X}$, which is obtained from the probit regression. The ATT measures the average difference in innovativeness between FFF participants and non-participants.

We use four different measures of the outcome variable, farmer innovativeness, to check if the results are sensitive to the indicator employed. The first (innovation_binary) is a binary variable which is equal to one if the household has, in the past 12 months, implemented any of the four categories of farmer innovation (i.e., invention of new practices or technologies, adaptation of exogenous ideas, modification of common or traditional practices and experimentation with new ideas), and 0 otherwise. The second (innovation_count) is a count variable that indicates the number of different innovation-generating activities implemented by a household in the past 12 months. In the third and fourth measure of FI, we consider the varied importance of each of the four categories of farmer innovation and constructed an innovation index using weights. In the third measure of FI (innovation index 1), we followed Filmer and Pritchett (2001) and used principal component analysis (PCA) to assign weights to each of the four innovation categories, and constructed a household innovation index. The final indicator (innovation index 2) also involves the construction of a household innovation index, but using weights obtained through expert judgements. A stakeholder workshop was organized, and 12 agricultural experts in the study region assigned weights to the four innovation categories based on an agreed level of importance for each category. They assigned weights of $0.4,0.2,0.3$ and 0.1 for invention, adaptation of exogenous ideas, modification of traditional practices and experimentation, respectively.

\footnotetext{
${ }^{3}$ The other two matching estimators also yield similar results of matching quality, but are not reported, for brevity.
} 


\section{Data}

The empirical analysis is based on data for the 2011-2012 agricultural season obtained from a household survey in the districts of Bongo, Kassena Nankana East and Kassena Nankana West in the Upper East Region, one of the poorest administrative regions of Ghana. The districts fall within the Sudan savanna agroecological zone. The area is characterized by a prolonged dry season and erratic rainfall. Agriculture is the main income source and a cereal-legume cropping system is predominant in the study region. The major crops are millet, sorghum, maize, cowpea, rice and groundnut. Most households also rear livestock.

The sample included FFF participants, non-participants from FFF communities and non-participants from control communities. We interviewed 409 households from 17 villages using a stratified random sampling. We first obtained from the district RTIMP project officers a list of all the 24 villages in the three districts where FFF had been implemented between 2008 and 2011. Then, we randomly selected ten participating villages across the three districts. We interviewed about 16-21 participants from each of these villages, resulting in a total of 185 FFF participants. We also obtained a list of all households in each of the FFF participating villages and randomly sampled and interviewed 99 non-participants across these villages. Since these non-participants are located in the FFF villages, they may potentially be exposed to some of the effects of FFF. To obtain a group of control farmers devoid of potential spillovers, we randomly selected seven villages (from the same three districts) that had similar infrastructural services and socio-economic conditions but not in close proximity to the FFF communities. Out of these, we randomly selected 125 farm households from a household list obtained from the District Agricultural Offices. Thus, our final sample consisted of 185 FFF participants and 224 non-participants, making a total of 409 sample farmers.

Data collection was conducted by experienced enumerators who were highly trained for this research. Interviews were conducted with the aid of pre-tested questionnaires and were supervised by the first author. The questionnaire captured data on household and plot characteristics, off-farm income earning activities, innovation-generating activities and access to infrastructural services, information and social interventions. The respondents were mainly FFF participants or household heads in the presence of other available household members.

\section{Descriptive Statistics}

In this section, we focus on four categories of farmer innovations. These are: developing new techniques or practices (hereafter, invention), adding value or modifying indigenous or traditional practices, modifying or adapting external techniques or practices to local conditions or farming systems and informal experimentation with original or external ideas. Thus, innovators are farm households 


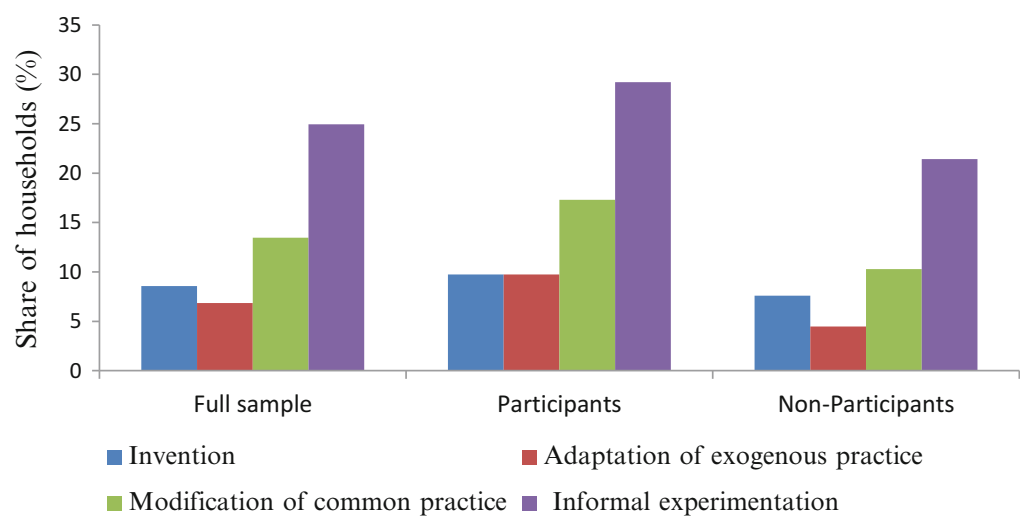

Fig. 10.1 Share of households that implemented innovation-generating activities

who have implemented any of these four categories of innovation-generating activities during the 12 months prior to the survey.

Figure 10.1 presents the share of households that implemented the four categories of innovation-generating activities and compares the results between participants and non-participants. Informal experimentation, which was implemented by $25 \%$ of the sample households, constitutes the most practiced activity. A similar trend is observed when we compare the innovation activities of FFF participants and non-participants. This is expected, as experimentation is the first stage of most innovation processes. The figure also shows that, relative to non-participants, FFF participants implemented more innovation-generating activities in each of the the four categories, which seems to suggest that FFF participation enhances innovation capacity. Examples of innovations include: informal trials with or introduction of new crops or varieties in a community; testing and modification of planting distance and cropping pattern; using plant extracts as insecticide; new formulations of animal feed and new herbal remedies in the treatment of livestock diseases (ethnoveterinary practices); developing and using new farming tools; storage of farm products using local grasses; and new methods of compost preparation.

Table 10.3 outlines the description and mean values of the outcome indicators and variables used in estimating the propensity scores. The table shows that about $42 \%$ of the sample households conducted at least one innovation-generating activity in the past 12 months.

\section{Probability of FFF Participation}

As mentioned, the first step in the PSM technique is the probit estimation of the propensity to participate in FFF, and the result is presented in Table 10.4. The result shows that FFF participation is influenced by household characteristics such as age, 
Table 10.3 Description and summary statistics of variables

\begin{tabular}{|c|c|c|c|}
\hline Variable & Description & Mean & SD \\
\hline \multicolumn{4}{|l|}{ Outcomes } \\
\hline Innovation_binary & $\begin{array}{l}\text { Household has conducted innovation-generating } \\
\text { activities (Binary) }\end{array}$ & 0.42 & 0.41 \\
\hline Innovation_count & $\begin{array}{l}\text { Number of innovation activities conducted by house- } \\
\text { hold (Count) }\end{array}$ & 0.59 & 0.79 \\
\hline Innovation index 1 & $\begin{array}{l}\text { Household innovation index based on weights } \\
\text { obtained through PCA }\end{array}$ & 0.00 & 1.00 \\
\hline Innovation index 2 & $\begin{array}{l}\text { Household innovation index based on weights } \\
\text { assigned by experts }\end{array}$ & 0.13 & 0.21 \\
\hline \multicolumn{4}{|l|}{ Covariates } \\
\hline Age & Age of household head & 49.42 & 14.88 \\
\hline Gender & Gender of household head (dummy, $1=$ male) & 0.86 & 0.35 \\
\hline Household size & Number of household members & 6.64 & 2.59 \\
\hline Dependency ratio & $\begin{array}{l}\text { Ratio of members aged below } 15 \text { and above } 64 \text { to } \\
\text { those aged } 15-64\end{array}$ & 0.89 & 0.79 \\
\hline Education & Education of household head (years) & 1.67 & 1.10 \\
\hline Land holding & Total land owned by household in acres & 4.56 & 4.15 \\
\hline Livestock holding & $\begin{array}{l}\text { Total livestock holding of household in Tropical } \\
\text { Livestock Units (TLU) }\end{array}$ & 2.92 & 3.41 \\
\hline Assets & Total value of non-land productive assets in $100 \mathrm{GH} \phi^{\mathrm{a}}$ & 4.54 & 6.92 \\
\hline Off-farm activities & $\begin{array}{l}\text { Household has access to off-farm income earning } \\
\text { activities }\end{array}$ & 0.76 & 0.43 \\
\hline Credit & Household has access to credit & 0.26 & 0.43 \\
\hline Road distance & Distance to nearest all-weather road in $\mathrm{km}$ & 0.54 & 0.84 \\
\hline Extremely risk averse & Household is extremely risk averse & 0.40 & 0.49 \\
\hline Severely risk averse & Household is severely risk averse & 0.22 & 0.42 \\
\hline $\begin{array}{l}\text { Intermediately risk } \\
\text { averse }\end{array}$ & Household is intermediately risk averse & 0.14 & 0.34 \\
\hline $\begin{array}{l}\text { Moderately risk } \\
\text { averse }\end{array}$ & Household is moderately risk averse & 0.04 & 0.20 \\
\hline $\begin{array}{l}\text { Slightly to neutral } \\
\text { risk averse }\end{array}$ & Household is slightly risk averse to risk neutral & 0.11 & 0.32 \\
\hline $\begin{array}{l}\text { Neutral to risk } \\
\text { preferring }\end{array}$ & Household is risk neutral to preferring & 0.09 & 0.30 \\
\hline
\end{tabular}

${ }^{\mathrm{a}}$ The exchange rate at the time of the survey was $\$ 1$ (US) $=\mathrm{GH} \phi 1.90$

gender of household head and household size. Participants are likely to be younger, and come from male-headed households of large size. Membership in a social group and credit accessibility also positively influence FFF participation. The negative and significant effect of road distance indicates that households living close to all-weather roads have a higher probability of participating in FFF. It is interesting to note that all the wealth-related covariates (i.e., land holding, productive assets, livestock holding and off-farm income) are not statistically significant. This seems to suggest that participation in FFF is inclusive of both resource-rich and resource-poor households. Finally, the result shows that a household's risk preferences do not affect FFF participation. 
Table 10.4 Probit estimation of the propensity score

\begin{tabular}{l|l|l}
\hline & Coefficient & Standard error \\
\hline Age & $-0.013^{* * *}$ & 0.01 \\
\hline Gender & $0.381^{*}$ & 0.20 \\
\hline Household size & $0.056^{* *}$ & 0.03 \\
\hline Dependency ratio & 0.057 & 0.08 \\
\hline Education & -0.013 & 0.02 \\
\hline Land holding & -0.019 & 0.02 \\
\hline Social group & $0.368^{* * *}$ & 0.14 \\
\hline Livestock holding & 0.019 & 0.02 \\
\hline Productive assets & 0.000 & 0.00 \\
\hline Off-farm income & -0.136 & 0.16 \\
\hline Credit access & $0.404^{* * *}$ & 0.15 \\
\hline Road distance & $-0.221^{* * *}$ & 0.08 \\
\hline Severely risk averse & 0.145 & 0.17 \\
\hline Intermediately risk averse & 0.19 & 0.21 \\
\hline Moderately risk averse & 0.237 & 0.35 \\
\hline Slightly to neutral risk averse & 0.226 & 0.22 \\
\hline Neutral to risk preferring & 0.343 & 0.24 \\
\hline Constant & -0.274 & 0.38 \\
\hline No. of observations & 409 & \\
\hline LR chi ${ }^{2}(17)$ & 46.75 & \\
\hline Prob $>$ chi ${ }^{2}$ & 0.000 & \\
\hline Pseudo ${ }^{2}$ & 0.083 &
\end{tabular}

\section{Effect of FFF Participation on Farmer Innovation}

The estimated ATT is presented in Table 10.5. We find positive and significant effect of FFF participation on farmer innovation irrespective of the matching algorithm or how the outcome variable is measured. Using the kernel matching approach, for instance, the results show that the rate of innovation generation by FFF participants is 13.4 percentage points higher relative to matched non-participants. Furthermore, FFF participants are more likely to implement between 0.24 and 0.31 more innovations than non-participants, depending on the matching technique. Overall, the results suggest that FFF participation consistently and robustly enhances innovativeness in farm households.

We also conducted tests on the sensitivity of estimates to unobservable factors (Rosenbaum 2002). Running mhbounds for binary outcome variables (Becker and Caliendo 2007), for example, we obtained a critical value of gamma, $\Gamma=1.40$ for kernel matching (model 1) which indicates that the ATT of 0.134 would be questionable only if matched pairs differ in their odds of FFF participation by a factor of $40 \%$. 
Table 10.5 PSM estimation of the effect of FFF participation on farmer innovation

\begin{tabular}{l|l|l|l}
\hline Matching algorithm $^{\mathrm{a}}$ & Outcome & ATT & SE \\
\hline Kernel matching & Innovation_binary & $0.134^{* * *}$ & 0.051 \\
\hline & Innovation_count & $0.239^{* * *}$ & 0.083 \\
\hline & Innovation index 1 & $0.268^{* * *}$ & 0.104 \\
\hline & Innovation index 2 & $0.054^{* *}$ & 0.022 \\
\hline Radius matching & Innovation_binary & $0.123^{* *}$ & 0.055 \\
\hline & Innovation_count & $0.235^{* * *}$ & 0.088 \\
\hline & Innovation index 1 & $0.255^{* *}$ & 0.111 \\
\hline Nearest neighbour & Innovation index 2 & $0.054^{* *}$ & 0.023 \\
\hline & Innovation_binary & $0.178^{* * *}$ & 0.055 \\
\hline & Innovation_count & $0.308^{* * *}$ & 0.089 \\
\hline & Innovation index 1 & $0.357^{* * *}$ & 0.112 \\
\hline & Innovation index 2 & $0.071^{* * *}$ & 0.024 \\
\hline
\end{tabular}

***,**, * represent $1 \%, 5 \%$, and $10 \%$ significance level, respectively

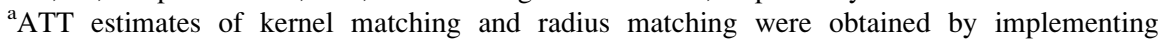
'psmatch2' command in Stata. ATT estimates of nearest neighbour matching were obtained using the 'teffects nnmatch' command with bias adjustment option in Stata 13

\section{Conclusions}

In this chapter, we explored the innovativeness of farmers in Upper East Ghana and evaluated whether farmer innovativeness can be stimulated by Farmer Field Fora, a platform for mutual learning and development of technologies and managerial skills. Using a farmer innovation contest with awards for the most innovative practices, we received 92 applications describing innovative and mostly technological approaches to farming. The results, therefore, indicate that farmers do actively develop innovations to address prevalent problems. Applying a propensity score matching approach, Farmer Field Fora were found to significantly and positively affect innovation generation. Overall, our results suggest good news with respect to the innovation capacity of farmers, and with respect to the ability of policy makers to foster this capacity. In light of global challenges such as climate change, fostering farmer innovation through Farmer Field Fora can therefore potentially act as a policy to enable autonomous adaptation.

Acknowledgements We thank the German Federal Ministry of Education and Research for funding within the WASCAL project (www.wascal.org). We are grateful for the support from the Ministry of Food and Agriculture (MOFA) in Ghana, as well as from the local farmers.

Open Access This chapter is distributed under the terms of the Creative Commons AttributionNoncommercial 2.5 License (http://creativecommons.org/licenses/by-nc/2.5/) which permits any noncommercial use, distribution, and reproduction in any medium, provided the original author(s) and source are credited.

The images or other third party material in this chapter are included in the work's Creative Commons license, unless indicated otherwise in the credit line; if such material is not included in the work's Creative Commons license and the respective action is not permitted by statutory regulation, users will need to obtain permission from the license holder to duplicate, adapt or reproduce the material. 


\section{Appendices}

\section{Appendix 1: List of Applications Received in Innovation Contest Rounds 2012 and 2013, as Well as Additional 20 Innovations Identified in Surveys}

\begin{tabular}{|c|c|c|}
\hline Location & ID & Name/Brief description of innovation \\
\hline $\begin{array}{l}\text { Bolgatanga } \\
\text { Municipal }\end{array}$ & 1 & Pisika (Cida acuta) \\
\hline $\begin{array}{l}\text { Bolgatanga } \\
\text { Municipal }\end{array}$ & 2 & Brooder house for poultry (local fowls \& guinea keets) \\
\hline $\begin{array}{l}\text { Bolgatanga } \\
\text { Municipal }\end{array}$ & 3 & Treatment of animal eyes using 'yaae' roots or bark \\
\hline $\begin{array}{l}\text { Bolgatanga } \\
\text { Municipal }\end{array}$ & 4 & Treatment of Alopecia using 'Sa-ire' \\
\hline $\begin{array}{l}\text { Bolgatanga } \\
\text { Municipal }\end{array}$ & 5 & Treatment of livestock using periga, kuka, anriga trees \\
\hline $\begin{array}{l}\text { Bolgatanga } \\
\text { Municipal }\end{array}$ & 6 & Organic manure farming \\
\hline $\begin{array}{l}\text { Bolgatanga } \\
\text { Municipal }\end{array}$ & 7 & Using fishpond water as liquid manure and insecticide \\
\hline $\begin{array}{l}\text { Bolgatanga } \\
\text { Municipal }\end{array}$ & 8 & Formulation of local fish feed \\
\hline Talensi Nabdam & 9 & Production of yogurt from milk obtained from cattle \\
\hline Talensi Nabdam & 10 & $\begin{array}{l}\text { Extraction of neem oil from neem seed for the spray of crops to control } \\
\text { pests }\end{array}$ \\
\hline Talensi Nabdam & 11 & Preparation of silage for feeding livestock \\
\hline Talensi Nabdam & 12 & Livestock feed formulation \\
\hline Talensi Nabdam & 13 & Neem extracts from neem seed \\
\hline $\begin{array}{l}\text { Bawku West } \\
\text { (Zebilla) }\end{array}$ & 14 & $\begin{array}{l}\text { Reducing guinea keet mortality by using sorghum malt plus pepper } \\
\text { water as dewormer }\end{array}$ \\
\hline $\begin{array}{l}\text { Bawku West } \\
\text { (Zebilla) }\end{array}$ & 15 & Barakuk - a herb for treating livestock wounds \\
\hline $\begin{array}{l}\text { Bawku West } \\
\text { (Zebilla) }\end{array}$ & 16 & Use of 'Yookat' herb to prevent and control termites \\
\hline $\begin{array}{l}\text { Bawku West } \\
\text { (Zebilla) }\end{array}$ & 17 & Use of 'Barakuk' to store seed \\
\hline $\begin{array}{l}\text { Bawku West } \\
\text { (Zebilla) }\end{array}$ & 18 & $\begin{array}{l}\text { Combination of three herbs to treat fowl pox: 'Baker', 'Gbangdang' } \\
\text { and 'Morag Kombri' }\end{array}$ \\
\hline $\begin{array}{l}\text { Bawku } \\
\text { Municipal }\end{array}$ & 19 & Honey with mahogany for treatment of intestinal works in guinea fowl \\
\hline $\begin{array}{l}\text { Bawku } \\
\text { Municipal }\end{array}$ & 20 & $\begin{array}{l}\text { Use of dry onion leaves to control striga weed in millet \& sorghum } \\
\text { fields }\end{array}$ \\
\hline Garu Tempane & 21 & Using neem seed oil for storage of crop seed \\
\hline Garu Tempane & 22 & $\begin{array}{l}\text { Herbal treatment for newly hatched chickens using 'Gbenatun' \& } \\
\text { Mango tree bark }\end{array}$ \\
\hline Garu Tempane & 23 & Cowpea storage using wood ashes \\
\hline
\end{tabular}




\begin{tabular}{|c|c|c|}
\hline Location & ID & Name/Brief description of innovation \\
\hline $\begin{array}{l}\text { Kassena } \\
\text { Nankana }\end{array}$ & 24 & Improving hatchability of guinea fowl eggs \\
\hline $\begin{array}{l}\text { Kassena } \\
\text { Nankana }\end{array}$ & 25 & Improving survival rates of puppies \\
\hline $\begin{array}{l}\text { Kassena } \\
\text { Nankana }\end{array}$ & 26 & Anti-snake weed or plant \\
\hline Builsa & 27 & Sweet potato vine multiplication in artificial shade \\
\hline Builsa & 28 & Traditional means of seed preservation \\
\hline $\begin{array}{l}\text { Bolgatanga } \\
\text { Municipal }\end{array}$ & 29 & Introducing Southern crops to Bolgatanga municipality \\
\hline $\begin{array}{l}\text { Kassena } \\
\text { Nankana }\end{array}$ & 30 & Predator control for poultry \\
\hline Bongo & 31 & $\begin{array}{l}\text { Planting and eating of Dawadawa fruit against the traditional belief of } \\
\text { dying }\end{array}$ \\
\hline Bongo & 32 & Using salt solution as a seed dresser \\
\hline Bongo & 33 & Storing Bambara beans using solution from boiled shea tree bark \\
\hline Bongo & 34 & Kuka (mahogany) bark for the treatment of chicken diseases \\
\hline Bongo & 35 & Bicycle tube pieces with ku-enka for storage of seed and grain \\
\hline $\begin{array}{l}\text { Kassena } \\
\text { Nankana East }\end{array}$ & 36 & Salt for controlling striga weed \\
\hline $\begin{array}{l}\text { Kassena } \\
\text { Nankana East }\end{array}$ & 37 & Kenaf seed for hatching eggs \\
\hline $\begin{array}{l}\text { Kassena } \\
\text { Nankana West }\end{array}$ & 38 & Salt to control termite in rice field \\
\hline $\begin{array}{l}\text { Kassena } \\
\text { Nankana West }\end{array}$ & 39 & Peels of ebony and mahogany to control poultry diseases \\
\hline $\begin{array}{l}\text { Kassena } \\
\text { Nankana West }\end{array}$ & 40 & Onion to control poultry disease \\
\hline $\begin{array}{l}\text { Kassena } \\
\text { Nankana West }\end{array}$ & 41 & $\begin{array}{l}\text { Compost preparation using a mixture of animal droppings and farm } \\
\text { residue in a unique way }\end{array}$ \\
\hline $\begin{array}{l}\text { Kassena } \\
\text { Nankana East }\end{array}$ & 42 & $\begin{array}{l}\text { Control of nematodes using a mixture of salt solution and fungicide } \\
\text { (rodimil plus) }\end{array}$ \\
\hline $\begin{array}{l}\text { Kassena } \\
\text { Nankana East }\end{array}$ & 43 & $\begin{array}{l}\text { Control of stubborn weed (Digitaria spp.) using a mixture of diesel, } \\
\text { water and weedicide }\end{array}$ \\
\hline $\begin{array}{l}\text { Kassena } \\
\text { Nankana West }\end{array}$ & 44 & Hatching of guinea fowl eggs using cotton and rag \\
\hline $\begin{array}{l}\text { Kassena } \\
\text { Nankana East }\end{array}$ & 45 & Bark of Goa tree to treat Newcastle disease in poultry \\
\hline $\begin{array}{l}\text { Kassena } \\
\text { Nankana West }\end{array}$ & 46 & Neem leaves to spray pepper and tomato against pests and diseases \\
\hline $\begin{array}{l}\text { Kassena } \\
\text { Nankana West }\end{array}$ & 47 & $\begin{array}{l}\text { Semi-intensive type of guinea fowl production, i.e., using mud to } \\
\text { construct walls, and coops for laying with trees inside to provide } \\
\text { shading }\end{array}$ \\
\hline $\begin{array}{l}\text { Kassena } \\
\text { Nankana East }\end{array}$ & 48 & Spraying Gloriosa fruit solution to treat vegetable pests \\
\hline $\begin{array}{l}\text { Kassena } \\
\text { Nankana West }\end{array}$ & 49 & $\begin{array}{l}\text { Mixing millet seeds with dry cell content before planting to prevent } \\
\text { worms from destroying the seeds }\end{array}$ \\
\hline
\end{tabular}




\begin{tabular}{|c|c|c|}
\hline Location & ID & Name/Brief description of innovation \\
\hline $\begin{array}{l}\text { Bolgatanga } \\
\text { Municipal }\end{array}$ & 50 & Control of Newcastle Disease in poultry using Dawadawa \\
\hline $\begin{array}{l}\text { Bolgatanga } \\
\text { Municipal }\end{array}$ & 51 & Prevention of fowl pox in poultry using Gubgo grass \\
\hline $\begin{array}{l}\text { Bolgatanga } \\
\text { Municipal }\end{array}$ & 52 & Mushroom production in dry environment \\
\hline $\begin{array}{l}\text { Kassena } \\
\text { Nankana West }\end{array}$ & 53 & Tree forest management \\
\hline $\begin{array}{l}\text { Kassena } \\
\text { Nankana West }\end{array}$ & 54 & Pest management in pepper \\
\hline $\begin{array}{l}\text { Kassena } \\
\text { Nankana West }\end{array}$ & 55 & Using secret groves to conserve forest \\
\hline $\begin{array}{l}\text { Kassena } \\
\text { Nankana West }\end{array}$ & 56 & Preparation and application of liquid organic manure \\
\hline $\begin{array}{l}\text { Bawku } \\
\text { Municipal }\end{array}$ & 57 & Preservation of Bambara nut \\
\hline $\begin{array}{l}\text { Bawku } \\
\text { Municipal }\end{array}$ & 58 & Raw ebony fruit solution for treatment of fowl pox \\
\hline $\begin{array}{l}\text { Bawku } \\
\text { Municipal }\end{array}$ & 59 & Preventing swollen gums and bleeding in animals \\
\hline $\begin{array}{l}\text { Bawku } \\
\text { Municipal }\end{array}$ & 60 & Controlling worms and ticks using barakuk plant ruminants \\
\hline $\begin{array}{l}\text { Bawku } \\
\text { Municipal }\end{array}$ & 61 & Treatment of foot and mouth disease in cattle using the "Pelinga" tree \\
\hline Pusiga & 62 & $\begin{array}{l}\text { Treatment of boils and skin diseases in ruminants using the bark of } \\
\text { mahogany }\end{array}$ \\
\hline Pusiga & 63 & $\begin{array}{l}\text { Treatment of snake bite using water drained from boiled dawadawa } \\
\text { seeds }\end{array}$ \\
\hline $\begin{array}{l}\text { Bawku } \\
\text { Municipal }\end{array}$ & 64 & Destroying termites during storage \\
\hline Pusiga & 65 & Controlling worms in dogs \\
\hline Pusiga & 66 & Controlling rickets in chicks \\
\hline Pusiga & 67 & Controlling worm infestation in guinea fowls using "Gberige" roots \\
\hline $\begin{array}{l}\text { Bawku } \\
\text { Municipal }\end{array}$ & 68 & $\begin{array}{l}\text { Treatment of chicken pox in poultry and fowl pox in poultry using } \\
\text { henna paste solution }\end{array}$ \\
\hline Binduri & 69 & Using millet ash solutions and salt petre solution to treat fowl pox \\
\hline Binduri & 70 & Mahogany and neem extracts as water medications for poultry diseases \\
\hline Binduri & 71 & Preservation and sweet potatoes \\
\hline Binduri & 72 & Neem tree leaves to store maize \\
\hline Builsa South & 73 & Treatment of guinea keets with kornamunig \\
\hline Builsa North & 74 & "Kwasuik" plant for storage of seeds \\
\hline Builsa North & 75 & Using striga plant as mosquito killer in rooms and surrounding \\
\hline Builsa North & 76 & Deworming ruminants with "kpalik "plant \\
\hline Garu Tempane & 77 & $\begin{array}{l}\text { Growing maize in the dry season using residual rainfall and white } \\
\text { Volta breeze }\end{array}$ \\
\hline Garu Tempane & 78 & Community-based extension agents \\
\hline
\end{tabular}




\begin{tabular}{l|l|l}
\hline Location & ID & Name/Brief description of innovation \\
\hline Garu Tempane & 79 & Onion seed and seedlings resistant to excessive rainfall and diseases \\
\hline Garu Tempane & 80 & Zero tillage and fertilizer in water melon production in the dry season \\
\hline Garu Tempane & 81 & Training dogs to watch tethered animals \\
\hline Garu Tempane & 82 & $\begin{array}{l}\text { Preventing termite attack on roots of seedlings (Mango, accasia) using } \\
\text { earth worm }\end{array}$ \\
\hline Garu Tempane & 83 & Maggot production for feeding chicks \\
\hline Garu Tempane & 84 & Cyclical brooding fowl (increased brooding cycle) \\
\hline Garu Tempane & 85 & Biological control of termites on young seedlings using tiger ants \\
\hline Garu Tempane & 86 & Using artificial methods other than incubators to hatch eggs \\
\hline Nabdam & 87 & All crop protection for storage using dabokuka plant \\
\hline Nabdam & 88 & $\begin{array}{l}\text { Deterring termites, especially on maize fields, using the "Wacutik" } \\
\text { plant }\end{array}$ \\
\hline Nabdam & 89 & Jetropher life fencing as snake repellent \\
\hline Nabdam & 90 & Effect of micro climate in cocoe plant to fruit \\
\hline Nabdam & 91 & Provision meeting ground (place) using afforestation \\
\hline Nabdam & 92 & Livestock bones for poultry/pig feed formulation \\
\hline
\end{tabular}

\section{Appendix 2: Test of Matching Quality (Kernel Matching)}

\begin{tabular}{l|l|l|l|l|l|l}
\hline & \multicolumn{5}{l}{ Unmatched } & \multicolumn{5}{l}{ Matched } \\
& Participants & $\begin{array}{l}\text { Non- } \\
\text { participants }\end{array}$ & t-test & Participants & $\begin{array}{l}\text { Non- } \\
\text { participants }\end{array}$ & t-test \\
\hline Age & 47.03 & 51.81 & $3.20^{* * *}$ & 47.11 & 48.82 & 0.39 \\
\hline Gender & 0.89 & 0.82 & $2.12^{* *}$ & 0.89 & 0.88 & -0.15 \\
\hline Household size & 6.90 & 6.38 & $2.05^{* *}$ & 6.86 & 6.61 & -0.16 \\
\hline $\begin{array}{l}\text { Dependency } \\
\text { ratio }\end{array}$ & 0.92 & 0.86 & 0.89 & 0.92 & 0.90 & -0.05 \\
\hline Education & 2.77 & 2.39 & 0.91 & 2.78 & 2.65 & 0.10 \\
\hline Land holding & 4.51 & 4.60 & -0.21 & 4.50 & 4.39 & 0.05 \\
\hline Social group & 0.46 & 0.34 & $2.50^{* *}$ & 0.46 & 0.41 & -0.46 \\
\hline $\begin{array}{l}\text { Livestock } \\
\text { holding }\end{array}$ & 3.02 & 2.56 & 1.37 & 3.03 & 2.63 & -0.03 \\
\hline Assets & 4.67 & 4.41 & 0.36 & 4.67 & 4.69 & -0.12 \\
\hline $\begin{array}{l}\text { Off-farm } \\
\text { activities }\end{array}$ & 0.76 & 0.75 & 0.05 & 0.76 & 0.77 & -0.21 \\
\hline Credit access & 0.32 & 0.19 & $3.10^{* * *}$ & 0.33 & 0.25 & -0.13 \\
\hline Road distance & 0.42 & 0.64 & $-2.55^{* *}$ & 0.43 & 0.46 & -0.04 \\
\hline $\begin{array}{l}\text { Extremely risk } \\
\text { averse (RA) }\end{array}$ & 0.36 & 0.44 & $-1.66^{*}$ & 0.36 & 0.39 & 0.70 \\
\hline Severely RA & 0.22 & 0.22 & -0.17 & 0.22 & 0.23 & -0.18 \\
\hline $\begin{array}{l}\text { Intermediately } \\
\text { RA }\end{array}$ & 0.14 & 0.13 & 0.17 & 0.14 & 0.14 & 0.06 \\
\hline & & & & & & \\
\hline
\end{tabular}




\begin{tabular}{|c|c|c|c|c|c|c|}
\hline & \multicolumn{3}{|l|}{ Unmatched } & \multicolumn{3}{|l|}{ Matched } \\
\hline & Participants & $\begin{array}{l}\text { Non- } \\
\text { participants }\end{array}$ & t-test & Participants & $\begin{array}{l}\text { Non- } \\
\text { participants }\end{array}$ & t-test \\
\hline $\begin{array}{l}\text { Moderately } \\
\text { RA }\end{array}$ & 0.05 & 0.03 & 0.90 & 0.05 & 0.04 & -0.36 \\
\hline $\begin{array}{l}\text { Slight to risk } \\
\text { neutral }\end{array}$ & 0.13 & 0.10 & 0.85 & 0.13 & 0.12 & 0.00 \\
\hline $\begin{array}{l}\text { Neutral to risk } \\
\text { preferring }\end{array}$ & 0.11 & 0.08 & 1.30 & 0.11 & 0.08 & -0.26 \\
\hline Median bias & & 9.10 & & & 3.10 & \\
\hline $\begin{array}{l}\text { Pseudo } \\
\text { R-squared }\end{array}$ & & 0.08 & & & 0.00 & \\
\hline$p$-value of LR & & 0.00 & & & 1.00 & \\
\hline
\end{tabular}

\section{References}

Becker S, Caliendo M (2007) Sensitivity analysis for average treatment effects. Stata J 7(1):71-83

Braun A, Jiggins J, Röling N, van den Berg H, Snijders P (2006) A global survey and review of farmer field school experiences. International Livestock Research Institute, Nairobi/Endelea

Caliendo M, Kopeinig S (2008) Some practical guidance for the implementation of propensity score matching. J Econ Surv 22(1):31-72. doi:10.1111/j.1467-6419.2007.00527.x

Christensen C (1994) Agricultural research in Africa: a review of USAID strategies and experience, SD publication series, Technical paper No 3. Bureau for Africa, USAID Office of Sustainable Development, Washington, DC

Davis K, Nkonya E, Kato E, Mekonnen DA, Odendo M, Miiro R, Nkuba J (2012) Impact of farmer field schools on agricultural productivity and poverty in East Africa. World Dev 40 (2):402-413. doi:10.1016/j.worlddev.2011.05.019

Filmer D, Pritchett LH (2001) Estimating wealth effects without expenditure data-or tears: an application to educational enrollments in states of India. Demography 38(1):115-132. doi:10. $2307 / 3088292$

Gbadugui BJ, Coulibaly O (2010) PRONAF's Farmer Field Fora (FFF). International Institute of Tropical Agriculture, Cotonou

Harrison GW, Rutström EE (2008) Risk aversion in the laboratory. Res Exp Econ 12:41-196

Reij C, Waters-Bayer A (eds) (2001) Farmer innovation in Africa. A source of inspiration for agricultural development. Earthscan, London

Rogers EM (2003) Diffusion of innovations, 5th edn. Free Press, New York

Rosenbaum PR (2002) Observational studies. Springer, New York

Rosenbaum PR, Rubin DB (1983) The central role of the propensity score in observational studies for causal effects. Biometrika 70(1):41-55. doi:10.1093/biomet/70.1.41

Scotchmer Z (2004) Innovation and incentives. The MIT Press, Cambridge, MA/London

Tambo JA, Wünscher T (2014) More than adopters: the welfare impacts of farmer innovation in rural Ghana. Paper presented at the 2014 Agricultural \& Applied Economics Association's (AAEA) annual meeting, Minneapolis, 27-29 July 2014 